\title{
AN AMMOBÆNETES FROM NEVADA (ORTHOPTERA; GRYLLACRIDIDÆ)
}

\author{
By H. F. Strohecker \\ Kenyon College
}

A few years ago Ira LaRivers of Reno, Nevada sent me, with other Orthoptera, a fine series ${ }^{1}$ of an undescribed species of gryllacridid. The specimens show the trimerous front and hind tarsi and crowded, long spurs on the hind tibiæ characteristic of Ammobcenetes Hubbell (1936). I have given to the species the name of its discoverer, who has made careful studies of Nevada insects. The use of spur and calcar below is that of Hubbell (1936, p. 16).

Ammobænetes lariversi n. sp.

Type, male. Sand Spring Dune, Churchill County, Nevada, July 5, 1941.

Considerably smaller than the only other described species, A. phrixocnemoides (Caudell). Front with a low, broad carina; eyes moderate in size, rather protuberant. Front coxa with a small, lateral spine. All the femora are unarmed. Hind femur stout, tapering rapidly at its apical third. Front tibia somewhat spindle-shaped, convex above, below convex on basal half, plane on apical half. The armament of the front tibia consists of a pair of dorsal calcars (the anterior $2 / 3$, the posterior $3 / 4$ as long as first tarsal joint), a pair of ventral calcars (anterior equal to, posterior much longer than, first tarsal joint), three short, slender spurs on the ventrocephalic carina and four large, blade-like spurs on the ventrocaudal carina. Claws of front tarsus asymmetric, the anterior longer. Middle tibia with four slender spurs on each dorsal edge, four slender spurs on ventrocephalic edge and one on ventrocaudal edge. The left middle tibia has three ventrocephalic and one ventrocaudal spur. The calcars of the middle tibia are proportioned as those of the front tibia but are much smaller. Claws of middle tarsus symmetrical, about equal to the shorter claw of front tarsus. Hind tibia \footnotetext{
ning.

${ }^{1}$ The specimens came to me in alcohol and were hardened in xylol before pin-
} 
broadest at its apical third, thence obliquely narrowed to apex, plane above. The dorsal surface of the tibia bears two small spurs on each margin, between which are small denticulations, and seven pairs of very long spurs (including dorsal calcars) on its apical third. Of these long spurs the more distal are subspatulate at the apex and those of the posterior or inner series
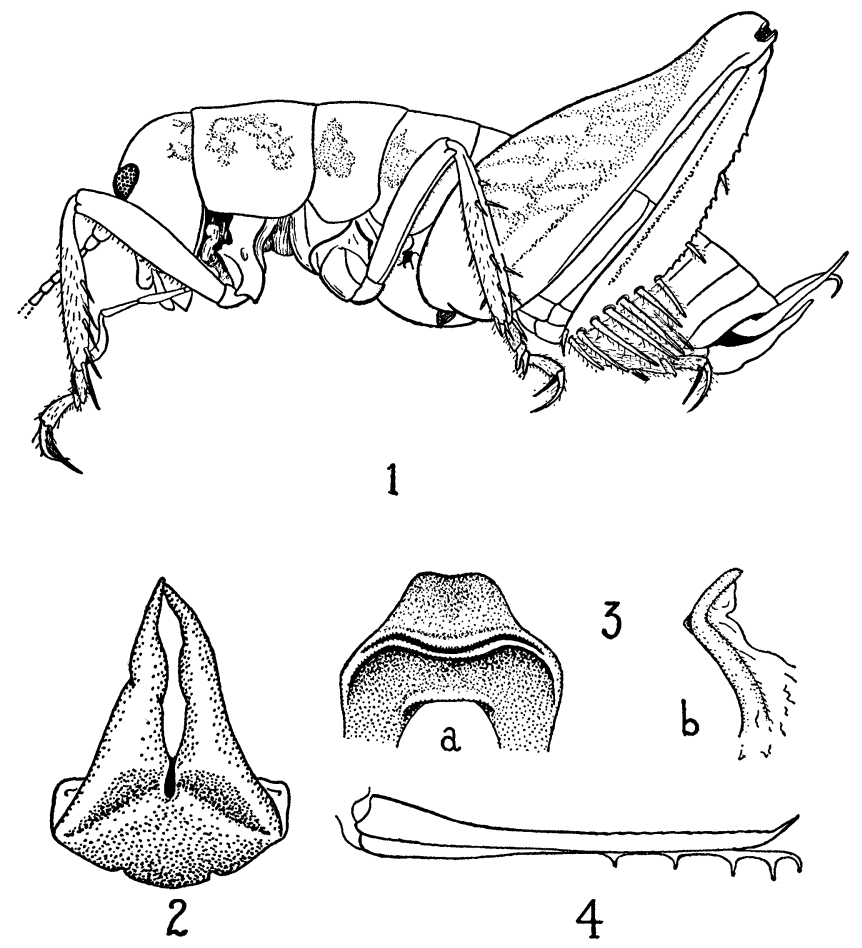

Fig. 1. Ammobanetes lariversi Strohecker. Type x10. Fig. 2. Subgenital plate of type. Fig. 3. Pseudosternite of paratype (a) posterior, (b) right lateral view. Fig. 4. Ovipositor of allotype.

are longer than those of the anterior. Ventral calcars of hind tibia short and slender. First joint of hind tarsus longer than the second and third together. Claws symmetrical, longer than claws of middle tarsus. Subgenital plate membranous, produced as two long, tapering processes. The color is pallid yellow-white with a slate colored band between the eyes on the front. The 
sides of the head, thorax, first few abdominal segments, hind femur and tibia are marked irregularly with similar color.

Length of pronotum $2.6 \mathrm{~mm}$; of hind femur $8.7 \mathrm{~mm}$.

Allotype: female. Data same as for type.

Similar to the type except in terminal abdominal structures and the following features: the left, front tibia has four ventrocephalic spurs; middle tibiæ each with three ventrocephalic and no ventrocaudal spurs. Subgenital plate entire, arcuately rounded. Ovipositor bulbous at base, rapidly narrowed in its proximal third, thence almost parallel. The dorsal margin of the upper valve is feebly crenulate in its distal half. The apex of the upper valve is upturned (about $30^{\circ}$ from horizontal) and aciculate. The lower valve is equipped with four, widely spaced, slender teeth and a decurved, apical hook. Length of pronotum $3 \mathrm{~mm}$.; of hind femur $9.5 \mathrm{~mm}$.; of ovipositor $7.2 \mathrm{~mm}$.

The series includes, besides the type and allotype, twenty males and forty-two females, all of which are designated paratypes. The entire lot was taken at Sand Spring Dune. Among the male specimens the minimum pronotal length (four specimens) is $2.5 \mathrm{~mm}$., the maximum (one specimen) $3 \mathrm{~mm}$. The other sixteen specimens all show a pronotal length 2.6-2.8 mm. The extremes of hind femur length are 8-10 mm., but sixteen specimens fall between $8.5-9.5 \mathrm{~mm}$. Pronotal extremes among the females are $2.8-3.6 \mathrm{~mm}$.; thirty-six of the specimens fall within the limits $3.0-3.5 \mathrm{~mm}$. Similar data for the hind femur are: extremes $8.8-11 \mathrm{~mm}$.; with thirty-five specimens within the limits $9.5-10.5 \mathrm{~mm}$. For the ovipositor the extremes are $6.6-8.3 \mathrm{~mm}$. All but three specimens fall within the limits $7.0-8.0 \mathrm{~mm}$.

The number of ventrocaudal spurs on the front tibia is a fairly constant feature, probably generic rather than specific. Five specimens show five ventrocaudal spurs on one front tibia, one has five spurs on each front tibia while one specimen has only three such spurs on one of its front tibiæ. The dorsal armament of the middle tibiæ is also rather constant. Four specimens have five spurs in the dorsocephalic series while three specimens have five spurs in the dorsocaudal series. None has a 5-5 armament and in all cases the aberration is unilateral. It is not correlated with sex. 


\section{Bibliography}

Caudell, A. N. 1907. A New Species of the Orthopterous Genus Daihinia. Entomological News 18:11-13.

1916. The Genera of the Tettiginiid Insects of the Subfamily Rhaphidophorinæ Found in America North of Mexico. Proc. U. S. National Museum 49:655-690.

Hubbell, T. H. 1936. A Monographic Revision of the Genus Ceuthophilus. Univ. Fla. Biol. Science Series 2(1): pp. $551+39 \mathrm{Pl}$. 

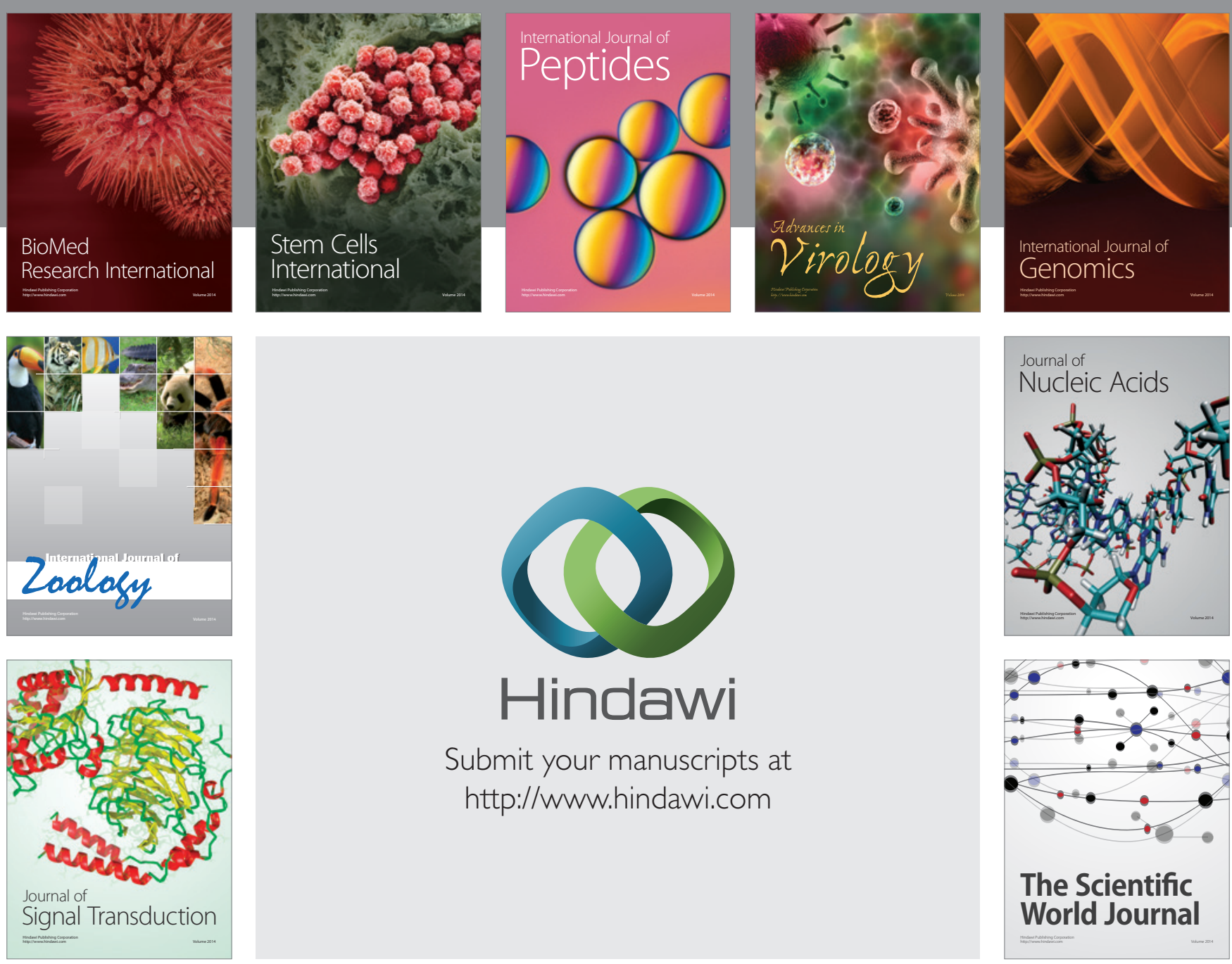

Submit your manuscripts at

http://www.hindawi.com
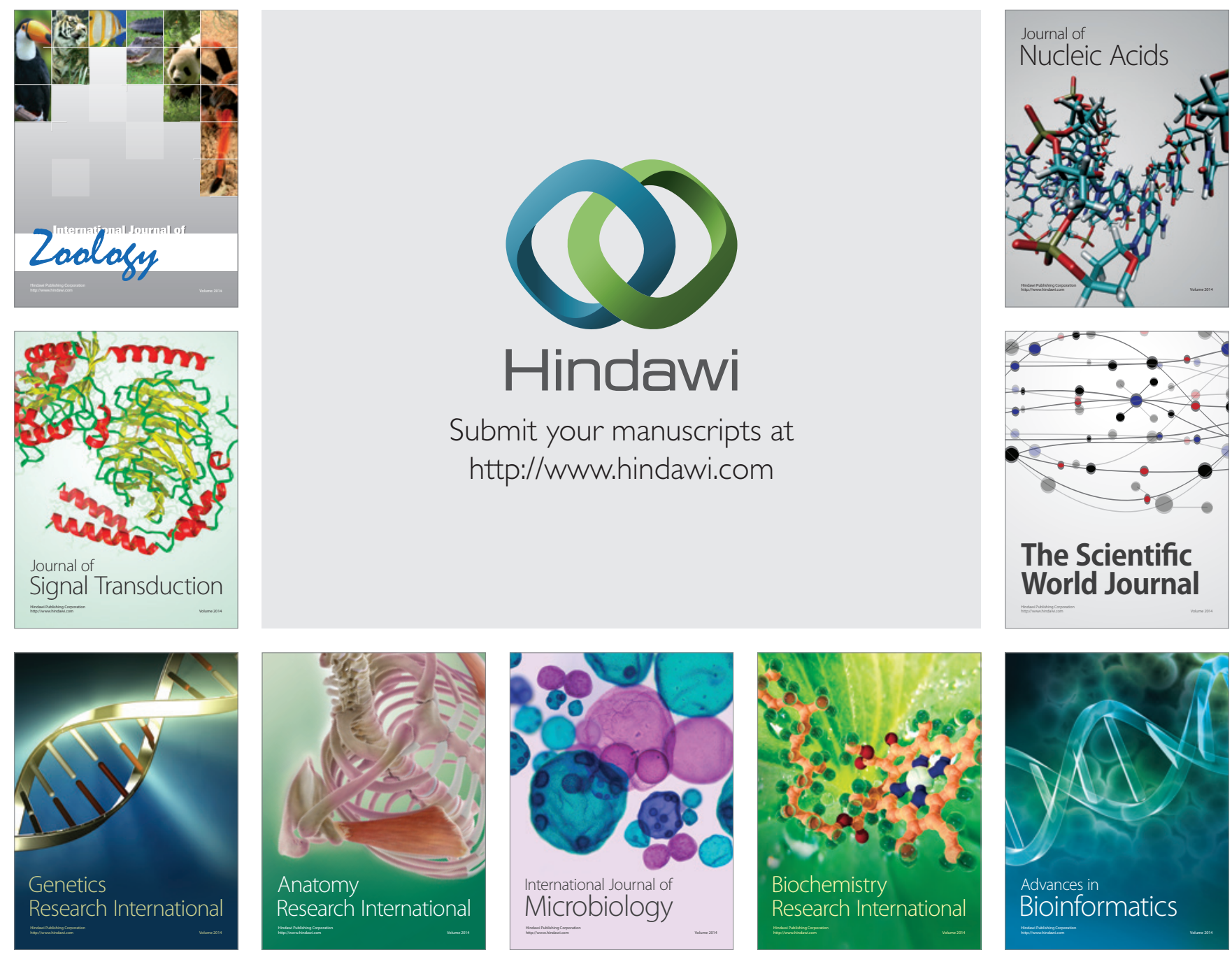

The Scientific World Journal
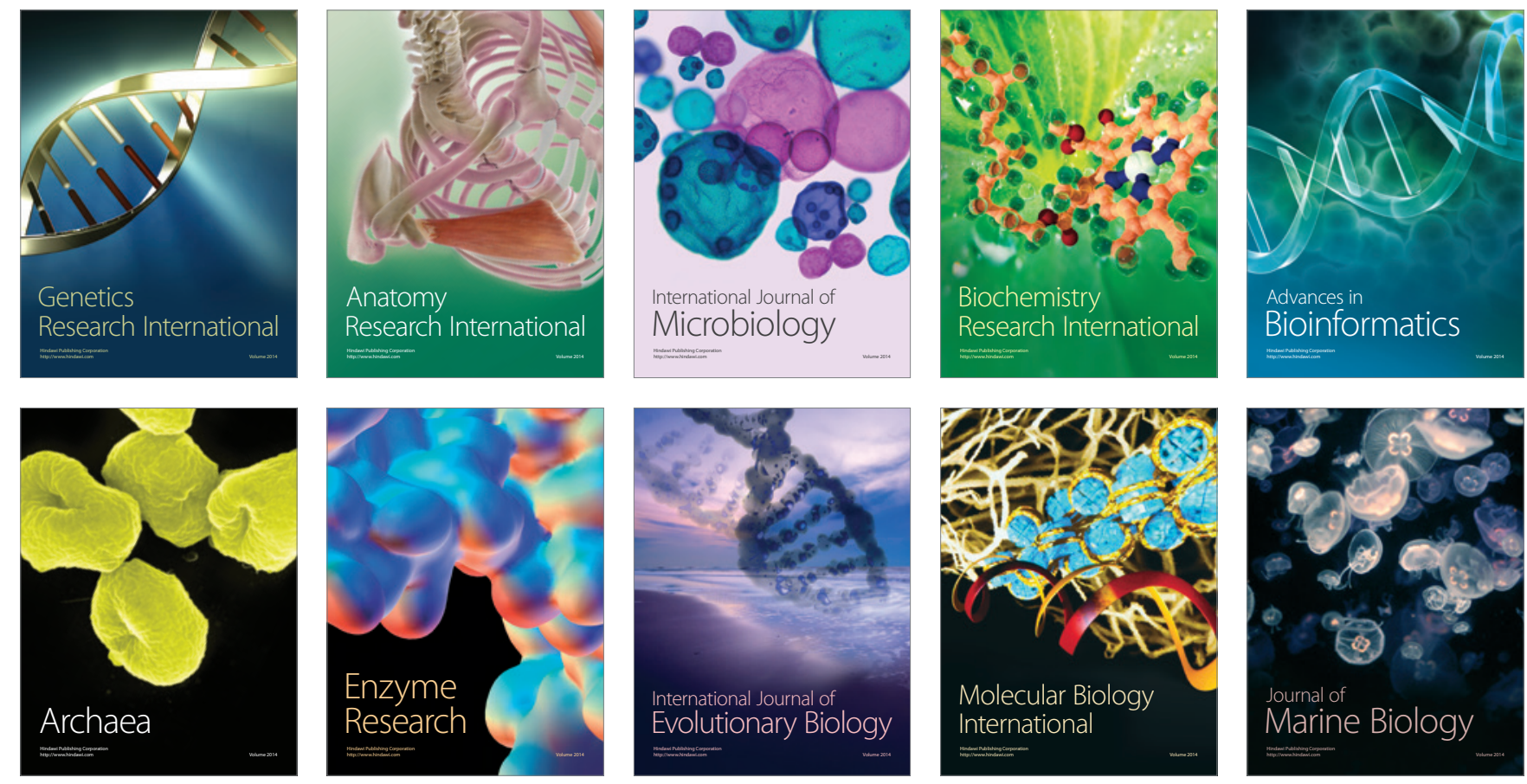